\title{
Investor Sentiment and Sectoral Stock Returns: Evidence from World Cup Games
}

\author{
Giuliano CURATOLA ${ }^{\mathrm{a}, *}$, Michael DONADELLI ${ }^{\mathrm{a}, 1}$, Renatas $\operatorname{KIZYS}^{\mathrm{b}, 2}$, Max RIEDEL ${ }^{\mathrm{a}, 3}$ \\ ${ }^{a}$ Research Center SAFE, Johann Wolfgang Goethe-University, House of Finance, Theodor-W.- Adorno Platz 3, 60323 Frankfurt am Main, \\ Germany \\ ${ }^{\mathrm{b}}$ Portsmouth Business School, Richmond Building Portland Street Portsmouth P01 3DE, United Kingdom
}

\section{A R T I C L E I N F O}

\section{Article history:}

Received 30 November 2015

Revised 11 February 2016

Accepted 25 March 2016

Available online 31 March 2016

\section{JEL Classification:}

A12

G14

Keywords:

Investor sentiment

soccer results

asset prices

market efficiency

\begin{abstract}
A B S T R A C T
It is well known that investor sentiment affects aggregate stock returns. We investigate the economic link between sport sentiment and US sectoral stock returns. We find that sport sentiment affects only the financial sector. We argue that this result might be explained by the high liquidity that makes the financial sector more attractive to foreign investors who in turn are more prone to sport sentiment than local investors in the US. Accordingly, an arbitrageur can build a profitable trading strategy by selling short the financial sector during the FIFA World cup periods and buying it back afterwards.
\end{abstract}

(c) 2016 Elsevier Inc. All rights reserved.

\section{Introduction}

An increasing number of empirical works suggests that investor sentiment has strong effects on asset prices. In these studies, different empirical measures of investor sentiment have been proposed. For instance, Saunders (1993) and Hirshleifer and Shumway (2003) consider sentiment effects driven by meteorological conditions. Kamstra et al. (2003) analyze the implication of seasonal affective diseases on asset prices while Bollena et al. (2011) propose to measure sentiment by using Twitter feeds. Edmans et al. (2007), Palomino et al. (2009), Kaplanski and Levy (2010a), Kaplanski and Levy (2010b), Kaplanski and Levy (2012) and Kaplanski and Levy (2014) measure investor sentiment using soccer results. Brown and Cliff (2004), Brown and Cliff (2005) and Lux (2011) identify sentiment using survey measures. Cao and Wei (2005) investigate the relation between stock market returns and temperature while Yuan et al. (2006) consider moon phases as a possible determinant of investor sentiment and study their impact on asset prices. Da et al. (2015) build an index of investors' fear using internet search volume.

\footnotetext{
* Tel.: +49 6979830096

E-mail addresses: curatola@safe.uni-frankfurt.de (G. CURATOLA), michael.donadelli@gmail.com (M. DONADELLI), renatas.kizys@port.ac.uk (R. KIZYS), riedel@safe.uni-frankfurt.de (M. RIEDEL).

1 Tel.: +4969798 33882

2 Tel.: +442392 844635

3 Tel.: +4969798 30069
} 
The empirical asset pricing literature typically studies the effect of different mood variables (i.e., variables capturing meteorological conditions, seasonal diseases, sport outcomes, etc.) on aggregate stock returns. However, it is reasonable to assume that different investors are prone to different kinds of sentiment. To the extent that different investors have different preferences for stocks trading, we expect that a given mood variable captures a particular relationship between sentiment and prices that is stronger for some stocks (or sectors) than others. In fact, Baker and Wurgler (2006) argue that investors "simply demand stocks that have the bundle of salient characteristics compatible with their sentiment".

Motivated by these observations we ask ourselves whether different US sectors are affected differently by investor sentiment. As a measure of investor sentiment we use results of World Cup games as in Kaplanski and Levy (2010a). We find a significant sentiment effect only for the financial industry while other sectors do not react significantly to changes in the investors' sport sentiment. To investigate the economic reasons behind this result we classify the US sectors according to different measures of liquidity and we find that the financial sector is consistently one of the most (if not the most) liquid sectors in our sample. To the extent that the sentiment effect is mainly induced by foreign investors, as suggested by Kaplanski and Levy (2010a), our finding is consistent with the observed preference of foreign investors for more liquid stocks (Dahlquist and Robertsson (2001)). Thus, one way to interpret our results in light of the argument of Baker and Wurgler (2006) is that foreign investors demand more financial stocks because their salient characteristic (i.e., high liquidity) is compatible with sport sentiment.

The rest of the paper is structured as follows: Section 2 summarizes the background for our analysis; Section 3 describes our econometric approach; Section 4 presents the results of our regression analysis; Section 5 illustrates a trading strategy that exploits the effect of sport sentiment; Section 6 concludes.

\section{Background and Motivation}

We seek to test the hypothesis that different sectors are affected differently by investor sentiment. Chen et al. (2013) analyse the effect of optimism and pessimism on stock returns of 11 Asian countries during the period 1996-2010. They find that sectoral stock returns react in different ways to local sentiment (measured as turnover by volume in local stock markets) and global sentiment (measured as turnover by volume in global stock markets). Similarly, Huang et al. (2014) build proxies for investor pessimism and optimism and find that optimism affects stock returns in most (but not all) US industries while pessimism has no effect on sectoral stock returns. Uygur and Tas (2014) use weekly trading volume of Istanbul Stock Exchange 100 as a proxy for investor sentiment and show that sentiment has a greater influence on industry, banking, and food and beverage sectors than on other sectors in Turkey. Admittedly, this literature is still fragmented to draw an educated conclusion. However, these results suggest that - despite investor sentiment being shown to affect the behavior of the aggregate stock market - it is plausible that this effect originates from individual sectors and then spills over to the entire market.

\section{Data and Methodology}

We employ Datastream Global Equity Indices (DGEI). In particular, we retrieve our ten sectoral stock indexes from level 2 of DGEI which divides the market into the following sectors: Basic Materials, Consumer Goods, Consumer Services, Financials, Health Care, Industrials, Oil \& Gas, Technology, Telecommunications and Utilities. ${ }^{4}$ Our sample covers 10,958 trading days, from January 1973 to December 2014. ${ }^{5}$ We compute continuously compounded day-to-day percentage returns and summarize their descriptive statistics in Table 1 below.

The empirical methodology is based on Kaplanski and Levy (2010a). Our sample includes 11 FIFA World Cups, with a total of 234 event effect days (EED) and 255 event period effect days (EPED) defined as follows: EED accounts for match days - which are also trading days - and the subsequent trading days; ${ }^{6}$ EPED covers the whole World Cup period, beginning on the day of the first match and continuing until the first day after the final match. The break days before the final game plus two additional trading days are also included ${ }^{7}$.

Our null hypothesis is thus that the US stock market - in each sector - is efficient and does not allow for exploitable arbitrage. The alternative hypothesis is that the World Cup effect - captured by EED and EPED - is statistically significant.

\footnotetext{
4 The use of DGEI represents a ubiquitous practice in empirical studies of international financial markets focused mainly on sectors (see, among others, Baca et al. (2000), Griffin and Stulz (2001), Brooks and Negro (2004), Nandha and Faff (2008), Donadelli and Paradiso (2014) and Donadelli and Persha (2014)).

${ }^{5}$ Notice that our sample is consistent with the analysis carried out by Edmans et al. (2007) who collect international soccer results from January 1973 through December 2004.

6 This is based on Edmans et al. (2007) who suggest that the local effect of a soccer game occurs the day after the game ends. We also implement tests when only days after the games are considered as EED. Results are almost identical and available upon request. The day of the game is included for the following reason: depending on where the games are hosted, the US market may still be open when the game ends. For all those games played during the week-end we assume they could have an effect on Monday (or the first available trading day).

7 The data for the World Cup are taken from www.worldcup-history.com.
} 
Table 1

Sector Returns.

\begin{tabular}{|c|c|c|c|c|c|c|c|c|c|c|}
\hline \multicolumn{11}{|c|}{ PANel A: Descriptive Statistics } \\
\hline Statistic & $\mathrm{BM}$ & CG & CS & $\mathrm{F}$ & $\mathrm{HC}$ & I & OG & $\mathrm{T}$ & TC & $\mathrm{U}$ \\
\hline Mean & 0.0361 & 0.0317 & 0.0358 & 0.0387 & 0.0444 & 0.0405 & 0.0427 & 0.0355 & 0.0354 & 0.0374 \\
\hline Med & 0.0158 & 0.017 & 0.0295 & 0.0234 & 0.0311 & 0.0203 & 0.0209 & 0.0208 & 0.0241 & 0.0356 \\
\hline Max & 14.506 & 9.031 & 10.979 & 13.519 & 11.444 & 9.298 & 17.335 & 15.699 & 13.28 & 13.408 \\
\hline Min & -22.297 & -22.64 & -22.915 & -18.194 & -19.29 & -21.405 & -22.212 & -24.492 & -19.925 & -14.214 \\
\hline StDev & 1.3708 & 1.1529 & 1.1926 & 1.3288 & 1.0279 & 1.1992 & 1.3908 & 1.5751 & 1.2032 & 0.9076 \\
\hline Skew & -0.733 & -0.7819 & -0.7363 & -0.3729 & -0.6834 & -0.758 & -0.5516 & -0.2298 & -0.31 & -0.2594 \\
\hline Kurt & 18.791 & 21.054 & 21.155 & 22.681 & 20.6 & 17.976 & 18.583 & 13.233 & 18.096 & 22.674 \\
\hline $\mathrm{J}-\mathrm{B}$ & $\begin{array}{l}114818 \\
(0.0000)\end{array}$ & $\begin{array}{l}149914 \\
(0.0000)\end{array}$ & $\begin{array}{l}151447 \\
(0.0000)\end{array}$ & $\begin{array}{l}177070 \\
(0.0000)\end{array}$ & $\begin{array}{l}142257 \\
(0.0000)\end{array}$ & $\begin{array}{l}103428 \\
(0.0000)\end{array}$ & $\begin{array}{l}111413 \\
(0.0000)\end{array}$ & $\begin{array}{l}47902 \\
(0.0000)\end{array}$ & $\begin{array}{l}104207 \\
(0.0000)\end{array}$ & $\begin{array}{l}176815 \\
(0.0000)\end{array}$ \\
\hline MV & 244,032 & 405,110 & 871,743 & $1,165,593$ & $1,020,932$ & 672,003 & 591,237 & $1,014,340$ & 284,455 & 261,923 \\
\hline Obs & 10956 & 10956 & 10956 & 10956 & 10956 & 10956 & 10956 & 10956 & 10956 & 10956 \\
\hline \multicolumn{11}{|c|}{ PANEL B: CoRrelations } \\
\hline & BM & CG & CS & $\mathrm{F}$ & $\mathrm{HC}$ & I & OG & $\mathrm{T}$ & $\mathrm{TC}$ & $\mathrm{U}$ \\
\hline Basic Materials & 1.00 & & & & & & & & & \\
\hline Consumer Goods & 0.72 & 1.00 & & & & & & & & \\
\hline Consumer Services & 0.76 & 0.80 & 1.00 & & & & & & & \\
\hline Financials & 0.73 & 0.68 & 0.79 & 1.00 & & & & & & \\
\hline Health Care & 0.69 & 0.70 & 0.79 & 0.71 & 1.00 & & & & & \\
\hline Industrials & 0.82 & 0.78 & 0.86 & 0.81 & 0.77 & 1.00 & & & & \\
\hline Oil \& Gas & 0.69 & 0.54 & 0.58 & 0.56 & 0.58 & 0.63 & 1.00 & & & \\
\hline Technology & 0.62 & 0.66 & 0.76 & 0.64 & 0.62 & 0.76 & 0.48 & 1.00 & & \\
\hline Telecommunications & 0.57 & 0.59 & 0.66 & 0.63 & 0.61 & 0.66 & 0.47 & 0.59 & 1.00 & \\
\hline Utilities & 0.60 & 0.56 & 0.58 & 0.60 & 0.61 & 0.61 & 0.59 & 0.44 & 0.57 & 1.00 \\
\hline
\end{tabular}

Notes: Panel A summarizes the descriptive statistics (mean, median, maximum, minimum, standard deviation, skewness, kurtosis, and the JarqueBera statistic) of continuously compounded day-to-day percentage returns on 10 stock market sectors in the United States. BM $=$ Basic Materials, CG $=$ Consumer Goods, CS = Consumer Services, F = Financials, HC = Health Care, I = Industrials, OG = Oil \& Gas, T= Technology, TC = Telecommunications, $\mathrm{U}=$ Utilities. Market value (MV) is displayed in million units of local currency (i.e., US\$). Panel B reports the correlation between sectoral stock market returns. Data are from DGEI and run from 01/01/1973 to 12/31/2014.

We test the null hypothesis - for each sector - using the following regression model: ${ }^{8}$

$$
R_{t}^{S}=\delta_{0}+\sum_{i=1}^{2} \delta_{1, i} R_{t-i}^{S}+\sum_{i=1}^{4} \delta_{2, i} D_{i, t}+\delta_{3} T_{t}+\delta_{4} P_{t}+\delta_{5} H B_{t}+\delta_{6} H_{t}+\delta_{7} E_{t}+\sum_{i=1}^{2} \delta_{8, i} J_{i, t}+u_{t}
$$

where $R_{t}^{s}$ is the daily return of sector $s ; \delta_{0}$ is a constant; $R_{t-i}^{s}$ is the previous ith day rate of return. $D_{i, t}$, with $i=1,2,3,4$, are dummy variables for the days of the week from Monday to Thursday, $T_{t}$ is a dummy variable for the first five days of the taxation year, $P_{t}$ is a dummy variable capturing the annual event period, $H B_{t}$ is the home bias dummy taking a value of one if the US soccer team wins a match and zero otherwise, $H_{t}$ is a dummy variable for days after non-weekend holidays, and $E_{t}$ stands for event days. In addition, $J_{i, t}$, with $i=1,2$ are dummy variables for the 10 days with the lowest $(i=1)$ and highest $(i=2)$ returns in our sample. Finally, $u_{t}$ is the error term.

\section{Regression Results}

To study the relationship between stock returns and sport sentiment we follow the procedure illustrated by Kaplanski and Levy (2010a). First, we estimate Eq. (1) using an OLS regression (Tables 2). To address potential heteroskedasticity issues we repeat the test assuming that the variance of the error term follows a GARCH $(1,1)$ process. By inspection of Table 2 we observe that the EED dummy variable has a negative effect on stock returns. The behavioral argument for this result is the following: investors enter a state of bad mood on the day after the team they support loses a match and they decide to sell stocks, thus, inducing stock returns to decrease. However, this effect is significant only for the Financials and the Telecommunications sectors. ${ }^{9}$ The sentiment effect is even more evident when we control for heteroskedasticity. From Figure 1 we observe that the p-value for the significance test of the sentiment coefficient $\left(\delta_{7}\right)$ is close to zero for all models applied to the Financials sector. For the Consumption Goods sector and the Telecommunications sector the p-value is close to zero only for some regression specifications but is relatively large for other specifications. For other sectors the sentiment coefficient is not significant supporting our claim that those sectors are not affected by sport sentiment. ${ }^{10}$

\footnotetext{
${ }^{8}$ A similar methodology can be found in Kamstra et al. (2003) and Edmans et al. (2007).

${ }^{9}$ The use of the EPED dummy gives rise to similar results. Detailed results available in the Supplementary Appendix.

${ }^{10}$ Note that the scale of the $\mathrm{y}$ axis is inverted so that high p-values are plotted at the bottom of the Figure and low p-values at the top.
} 
Table 2

Regression Results (ALL SECTORS)

\begin{tabular}{|c|c|c|c|c|c|c|c|c|c|c|c|c|c|c|c|}
\hline Eqs & $\delta_{0}$ & $\begin{array}{l}\delta_{1,1} \\
R_{t-1}^{s}\end{array}$ & $\begin{array}{l}\delta_{1,2} \\
R_{t-2}^{s}\end{array}$ & $\begin{array}{l}\delta_{2,1} \\
D_{1, t}\end{array}$ & $\begin{array}{l}\delta_{2,2} \\
D_{2, t}\end{array}$ & $\begin{array}{l}\delta_{2,3} \\
D_{3, t}\end{array}$ & $\begin{array}{l}\delta_{2,4} \\
D_{4, t}\end{array}$ & $\begin{array}{l}\delta_{3} \\
T_{t}\end{array}$ & $\begin{array}{l}\delta_{4} \\
P_{t}\end{array}$ & $\begin{array}{l}\delta_{5} \\
H B_{t}\end{array}$ & $\begin{array}{l}\delta_{6} \\
H_{t}\end{array}$ & $\begin{array}{l}\delta_{7} \\
E_{t}\end{array}$ & $\begin{array}{l}\delta_{8,1} \\
J_{1, t}\end{array}$ & $\begin{array}{l}\delta_{8,2} \\
J_{2, t}\end{array}$ & $\log L$ \\
\hline & \multicolumn{15}{|c|}{ BASIC Materials } \\
\hline $\begin{array}{l}\text { Coeff } \\
\text { Signif }\end{array}$ & $\begin{array}{l}0.0641 * \\
(0.0157) \\
\text { ConsumER }\end{array}$ & $\begin{array}{l}0.0456 * * \\
(0.0040) \\
\text { Goods }\end{array}$ & $\begin{array}{l}0.0181 \\
(0.2190)\end{array}$ & $\begin{array}{l}-0.1013 * * \\
(0.0078)\end{array}$ & $\begin{array}{l}-0.0092 \\
(0.8085)\end{array}$ & $\begin{array}{l}0.0037 \\
(0.9217)\end{array}$ & $\begin{array}{l}-0.0299 \\
(0.4290)\end{array}$ & $\begin{array}{l}0.1985 * \\
(0.0394)\end{array}$ & $\begin{array}{l}-0.0107 \\
(0.7408)\end{array}$ & $\begin{array}{l}0.8466 \\
(0.1185)\end{array}$ & $\begin{array}{l}-0.0092 \\
(0.9037)\end{array}$ & $\begin{array}{l}-0.1185 \\
(0.1492)\end{array}$ & $\begin{array}{l}-12.1333 * * \\
(0.0000)\end{array}$ & $\begin{array}{l}9.4097 * * \\
(0.0000)\end{array}$ & -18304.64 \\
\hline $\begin{array}{l}\text { Coeff } \\
\text { Signif }\end{array}$ & $\begin{array}{l}0.0054 \\
(0.8176) \\
\text { CoNSUMER S }\end{array}$ & $\begin{array}{l}0.0355 * \\
(0.0233) \\
\text { SERVICES }\end{array}$ & $\begin{array}{l}-0.0009 \\
(0.9459)\end{array}$ & $\begin{array}{l}0.0242 \\
(0.4698)\end{array}$ & $\begin{array}{l}0.0286 \\
(0.3794)\end{array}$ & $\begin{array}{l}0.0516 \\
(0.1096)\end{array}$ & $\begin{array}{l}0.0177 \\
(0.5899)\end{array}$ & $\begin{array}{l}0.2300 * * \\
(0.0067)\end{array}$ & $\begin{array}{l}-0.0079 \\
(0.7698)\end{array}$ & $\begin{array}{l}0.8266 \\
(0.1974)\end{array}$ & $\begin{array}{l}0.0447 \\
(0.4791)\end{array}$ & $\begin{array}{l}-0.1048 \\
(0.1106)\end{array}$ & $\begin{array}{l}-8.8989 * * \\
(0.0000)\end{array}$ & $\begin{array}{l}6.7082 * * \\
(0.0000)\end{array}$ & -16594.40 \\
\hline $\begin{array}{l}\text { Coeff } \\
\text { Signif }\end{array}$ & $\begin{array}{l}0.0502 * \\
(0.0325) \\
\text { FINANCIALS }\end{array}$ & $\begin{array}{l}0.0692 * * \\
(0.0000)\end{array}$ & $\begin{array}{l}-0.0143 \\
(0.2933)\end{array}$ & $\begin{array}{l}-0.0679 * \\
(0.0413)\end{array}$ & $\begin{array}{l}0.0038 \\
(0.9104)\end{array}$ & $\begin{array}{l}0.0147 \\
(0.6547)\end{array}$ & $\begin{array}{l}0.0061 \\
(0.8573)\end{array}$ & $\begin{array}{l}0.0477 \\
(0.5457)\end{array}$ & $\begin{array}{l}-0.0225 \\
(0.4224)\end{array}$ & $\begin{array}{l}0.7297 \\
(0.1678)\end{array}$ & $\begin{array}{l}-0.0195 \\
(0.7637)\end{array}$ & $\begin{array}{l}-0.1085 \\
(0.1269)\end{array}$ & $\begin{array}{l}-9.6109 * * \\
(0.0000)\end{array}$ & $\begin{array}{l}7.3859 * * \\
(0.0000)\end{array}$ & -16887.19 \\
\hline $\begin{array}{l}\text { Coeff } \\
\text { Signif }\end{array}$ & $\begin{array}{l}0.0711 * * \\
(0.0056) \\
\text { HEALTH-CAR }\end{array}$ & $\begin{array}{l}-0.0019 \\
{ }_{E}^{(0.9293)}\end{array}$ & $\begin{array}{l}0.0152 \\
(0.4907)\end{array}$ & $\begin{array}{l}-0.1138 * * \\
(0.0018)\end{array}$ & $\begin{array}{l}-0.0023 \\
(0.9496)\end{array}$ & $\begin{array}{l}-0.0110 \\
(0.7551)\end{array}$ & $\begin{array}{l}-0.0185 \\
(0.6110)\end{array}$ & $\begin{array}{l}0.1032 \\
(0.2323)\end{array}$ & $\begin{array}{l}0.0030 \\
(0.9208)\end{array}$ & $\begin{array}{l}1.0409 \\
(0.1479)\end{array}$ & $\begin{array}{l}-0.0450 \\
(0.5222)\end{array}$ & $\begin{array}{l}-0.1806 * \\
(0.0143)\end{array}$ & $\begin{array}{l}-12.4538 * * \\
(0.0000)\end{array}$ & $\begin{array}{l}11.1080 * * \\
(0.0000)\end{array}$ & -17791.79 \\
\hline $\begin{array}{l}\text { Coeff } \\
\text { Signif }\end{array}$ & $\begin{array}{l}0.0315 \\
(0.1305) \\
\text { INDUSTRIALS }\end{array}$ & $\begin{array}{l}0.0658 * * \\
(0.0001)\end{array}$ & $\begin{array}{l}-0.0252 \\
(0.0596)\end{array}$ & $\begin{array}{l}-0.0140 \\
(0.6314)\end{array}$ & $\begin{array}{l}0.0670 * \\
(0.0221)\end{array}$ & $\begin{array}{l}0.0343 \\
(0.2323)\end{array}$ & $\begin{array}{l}0.0024 \\
(0.9329)\end{array}$ & $\begin{array}{l}-0.0609 \\
(0.4008)\end{array}$ & $\begin{array}{l}-0.0134 \\
(0.5868)\end{array}$ & $\begin{array}{l}0.3660 \\
(0.4410)\end{array}$ & $\begin{array}{l}-0.0476 \\
(0.4170)\end{array}$ & $\begin{array}{l}-0.0287 \\
(0.6621)\end{array}$ & $\begin{array}{l}-8.1363 * * \\
(0.0000)\end{array}$ & $\begin{array}{l}6.6788 * * \\
(0.0000)\end{array}$ & -15246.28 \\
\hline $\begin{array}{l}\text { Coeff } \\
\text { Signif }\end{array}$ & $\begin{array}{l}0.0517 * \\
(0.0320) \\
\text { OIL\&GAS }\end{array}$ & $\begin{array}{l}0.0571 * * \\
(0.0002)\end{array}$ & $\begin{array}{l}-0.0031 \\
(0.8287)\end{array}$ & $\begin{array}{l}-0.0564 \\
(0.0956)\end{array}$ & $\begin{array}{l}0.0164 \\
(0.6309)\end{array}$ & $\begin{array}{l}-0.0007 \\
(0.9839)\end{array}$ & $\begin{array}{l}0.0019 \\
(0.9566)\end{array}$ & $\begin{array}{l}0.0544 \\
(0.5302)\end{array}$ & $\begin{array}{l}-0.0202 \\
(0.4728)\end{array}$ & $\begin{array}{l}0.7922 \\
(0.1075)\end{array}$ & $\begin{array}{l}-0.0002 \\
(0.9975)\end{array}$ & $\begin{array}{l}-0.0781 \\
(0.2816)\end{array}$ & $\begin{array}{l}-9.4746 * * \\
(0.0000)\end{array}$ & $\begin{array}{l}7.4070 * * \\
(0.0000)\end{array}$ & -16980.64 \\
\hline $\begin{array}{l}\text { Coeff } \\
\text { Signif }\end{array}$ & $\begin{array}{l}0.0952 * * \\
(0.0004) \\
\text { TECHNOLOGY }\end{array}$ & $\begin{array}{l}0.0086 \\
(0.5754)\end{array}$ & $\begin{array}{l}-0.0325 * \\
(0.0159)\end{array}$ & $\begin{array}{l}-0.0981 * \\
(0.0102)\end{array}$ & $\begin{array}{l}-0.0363 \\
(0.3471)\end{array}$ & $\begin{array}{l}-0.0199 \\
(0.6112)\end{array}$ & $\begin{array}{l}-0.0754 * \\
(0.0472)\end{array}$ & $\begin{array}{l}0.0575 \\
(0.5866)\end{array}$ & $\begin{array}{l}-0.0126 \\
(0.7074)\end{array}$ & $\begin{array}{l}0.2524 \\
(0.6267)\end{array}$ & $\begin{array}{l}0.0115 \\
(0.8856)\end{array}$ & $\begin{array}{l}-0.1443 \\
(0.0774)\end{array}$ & $\begin{array}{l}-12.1076 * * \\
(0.0000)\end{array}$ & $\begin{array}{l}9.7633 * * \\
(0.0000)\end{array}$ & -18467.26 \\
\hline $\begin{array}{l}\text { Coeff } \\
\text { Signif }\end{array}$ & $\begin{array}{l}-0.0288 \\
(0.3535) \\
\text { TelECOMMUI }\end{array}$ & $\begin{array}{l}0.0127 \\
(0.3611) \\
\text { NICATIONS }\end{array}$ & $\begin{array}{l}-0.0220 \\
(0.1483)\end{array}$ & $\begin{array}{l}0.0876 * \\
(0.0449)\end{array}$ & $\begin{array}{l}0.0822 \\
(0.0715)\end{array}$ & $\begin{array}{l}0.1144 * * \\
(0.0096)\end{array}$ & $\begin{array}{l}0.0329 \\
(0.4574)\end{array}$ & $\begin{array}{l}0.1830 \\
(0.1135)\end{array}$ & $\begin{array}{l}-0.0047 \\
(0.9042)\end{array}$ & $\begin{array}{l}0.3707 \\
(0.6724)\end{array}$ & $\begin{array}{l}0.0230 \\
(0.8100)\end{array}$ & $\begin{array}{l}-0.1054 \\
(0.2836)\end{array}$ & $\begin{array}{l}-10.7029 * * \\
0.0000\end{array}$ & $\begin{array}{l}10.3772 \text { ** } \\
0.0000\end{array}$ & -20044.12 \\
\hline $\begin{array}{l}\text { Coeff } \\
\text { Signif }\end{array}$ & $\begin{array}{l}0.0663 * * \\
(0.0052) \\
\text { UTILITIES }\end{array}$ & $\begin{array}{l}0.0010 \\
(0.9480)\end{array}$ & $\begin{array}{l}-0.0080 \\
(0.6197)\end{array}$ & $\begin{array}{l}-0.0640 \\
(0.0573)\end{array}$ & $\begin{array}{l}-0.0221 \\
(0.5183)\end{array}$ & $\begin{array}{l}-0.0415 \\
(0.2160)\end{array}$ & $\begin{array}{l}-0.0327 \\
(0.3256)\end{array}$ & $\begin{array}{l}0.0584 \\
(0.5098)\end{array}$ & $\begin{array}{l}0.0150 \\
(0.5857)\end{array}$ & $\begin{array}{l}0.6503 \\
(0.1224)\end{array}$ & $\begin{array}{l}0.0451 \\
(0.4979)\end{array}$ & $\begin{array}{l}-0.1924 * \\
(0.0118)\end{array}$ & $\begin{array}{l}-8.9727 * * \\
(0.0000)\end{array}$ & $\begin{array}{l}9.0440 * * \\
(0.0000)\end{array}$ & -16969.48 \\
\hline $\begin{array}{l}\text { Coeff } \\
\text { Signif }\end{array}$ & $\begin{array}{l}0.0813 * * \\
(0.0000)\end{array}$ & $\begin{array}{l}0.0596 * * \\
(0.0020)\end{array}$ & $\begin{array}{l}0.0148 \\
(0.3491)\end{array}$ & $\begin{array}{l}-0.0588 * \\
(0.0188)\end{array}$ & $\begin{array}{l}-0.0638 * \\
(0.0111)\end{array}$ & $\begin{array}{c}-0.0540 * \\
(0.0293)\end{array}$ & $\begin{array}{l}-0.0515 * \\
(0.0391)\end{array}$ & $\begin{array}{l}0.0753 \\
(0.3038)\end{array}$ & $\begin{array}{l}-0.0047 \\
(0.8325)\end{array}$ & $\begin{array}{l}-0.3247 \\
(0.4899)\end{array}$ & $\begin{array}{l}-0.0268 \\
(0.5784)\end{array}$ & $\begin{array}{l}-0.0531 \\
(0.3519)\end{array}$ & $\begin{array}{l}-7.6080 * * \\
(0.0000)\end{array}$ & $\begin{array}{l}8.1624 * * \\
(0.0000)\end{array}$ & -13646.12 \\
\hline
\end{tabular}

Note: This table reports the results of the regression Eq. (1). Results of multiple linear regression models of continuously compounded day-to-day percentage returns on sectoral portfolios of Basic Materials, Consumer Goods, Consumer Services, Financials, Healthcare, Industrials, Oil\&Gas, Technology, Telecommunications and Utilities. The estimated equations are in rows, and the estimated coefficients are in columns. $R_{t}^{s}$ is the daily return of sector $s, \delta_{0}$ is a constant, $R_{t-i}^{s}$ is the previous ith day rate of return. $D_{i, t}$, with $i=1,2,3,4$, are dummy variables for the day of the week (i.e. Monday, Tuesday, Wednesday, and Thursday, respectively), $T_{t}$ is a dummy variable for the first five days of the taxation year, $P_{t}$ is a dummy variable capturing the annual event period, $H B_{t}$ is a dummy capturing a potential home bias effect in case of wins by the US soccer team, $H_{t}$ is a dummy variable for days after non-weekend holidays, and $E_{t}$ stands for event days (EED). In addition, $J_{i, t}$, with $i=1,2$ are dummy variables for the 10 days with the lowest $(i=1)$ and highest $(i=2)$ returns during the analyzed period. Finally, $u_{t}$ is the error term. The log-likelihood value of the estimated model is shown in the last column. The standard error estimates are robust to heteroskedasticity. We use daily data for the period January 1973 - December 2014 (a total of 10,958 observations). P-values are reported in parentheses. $*$ and ** indicate a significance level of $5 \%$ and $1 \%$, respectively. 


\section{Cross-Industry Sentiment Effect}

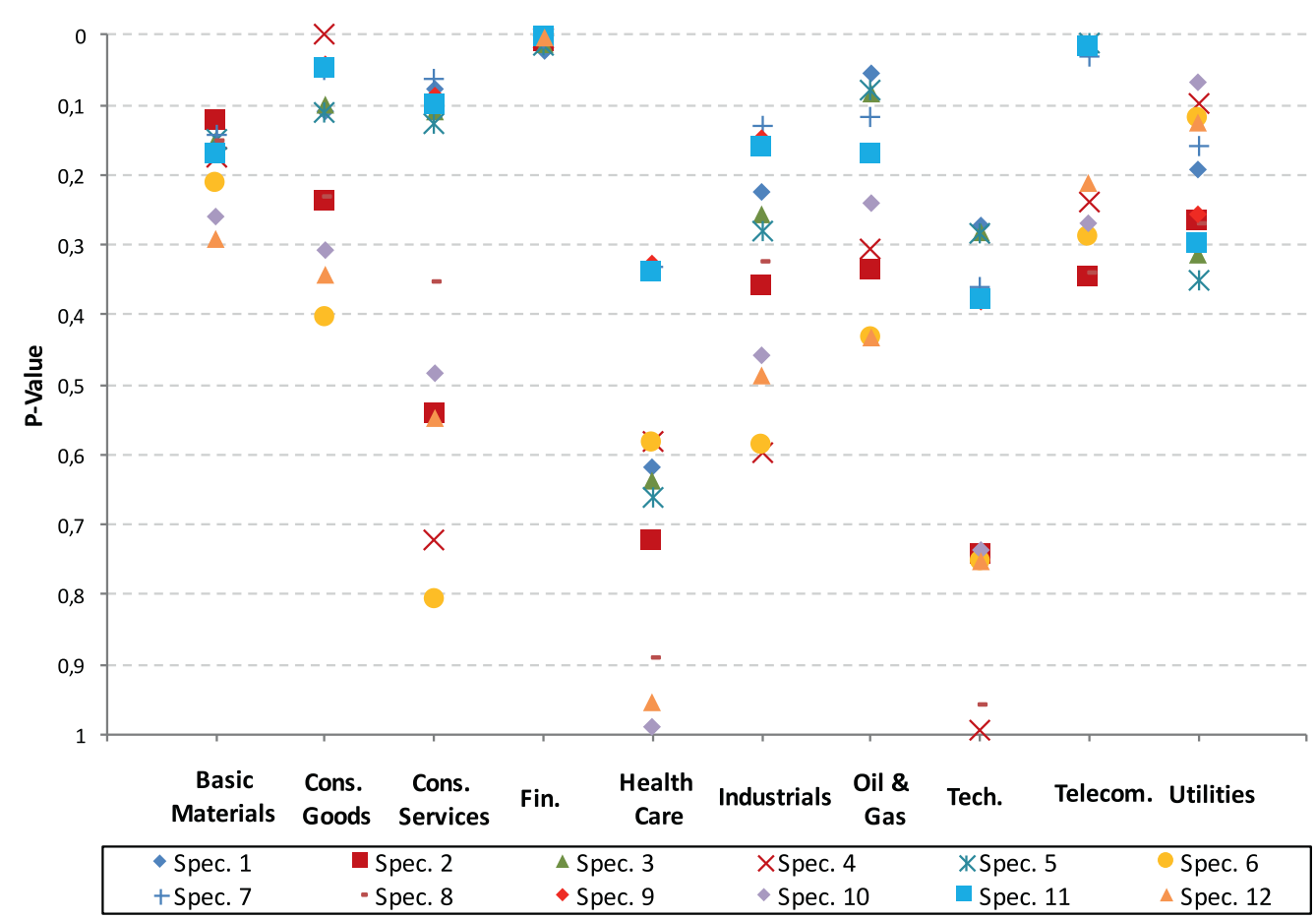

Fig. 1. Regression results. Notes: This Figure reports the p-values associated to the sentiment coefficient, $\delta_{7}$, obtained from twelve different regression specifications for each sector. Estimates for all the other coefficients are reported in the Supplementary Appendix. Spec. 1: linear model with event effect days only; Spec. 2: GARCH model with event effect days only; Spec. 3: linear model without serial correlation and event effect days; Spec. 4: GARCH model without serial correlation and event effect days; Spec. 5: Linear model with serial correlation and event effect days; Spec 6: GARCH model with serial correlation and event effect days; Spec. 7: linear model with event period effect days only; Spec. 8 : GARCH model with event period effect days only; Spec. 9: linear model without serial correlation and event period effect days; Spec 10: GARCH model without serial correlation and event period effect days; Spec. 11: linear model with serial correlation and event period effect days; Spec. 12: GARCH model with serial correlation and event period effect days.

We then turn to the relationship between sport sentiment and liquidity. ${ }^{11}$ Entries in Table 3 suggest that the Financials sector has the second highest level of liquidity as measured by annual turnover by volume and average turnover by volume. ${ }^{12}$ This suggests that sport sentiment affects liquid sectors more than illiquid sectors. After all, if investors enter a state of bad mood on the day after a match, it is reasonable to believe they may not want to sell stocks at a low price and, for this reason, they prefer to stay away from illiquid markets.

We also estimate the multiple linear regression model that features the EED dummy for the last two World Cups (2010 and 2014). The efficient market hypothesis suggests that the stock market behavior should diminish the scope of profitable trading strategies over time (Kaplanski and Levy (2014)). Indeed, for the Financials sector, the EED dummy does not exert a significant effect on stock returns. This finding agrees with Kaplanski and Levy (2014) who report similar results for the 2010 World Cup. To test whether the relationship between sport sentiment and stock returns depends on the US being the hosting country or not, we repeat the analysis by focusing only on the 1994 World Cup. For this particular year we find weaker evidence of the sentiment effect. ${ }^{13}$ Finally, for the sake of completeness we repeat the analysis for Germany, Italy and the UK. We find evidence of a sport sentiment effect for sectors different than Financials. For the UK the relevant sector is Oil \& Gas, for Germany Healthcare and Telecommunications while for Italy the relevant sectors are Consumer Services and Health Care. This result is in line with the main hypothesis that sport sentiment in the US market is mainly driven by foreign investors (also because soccer is not very popular among local investors in the US). ${ }^{14}$ Instead, European markets have a lower fraction of foreign investors and, at the same time, soccer is very popular among local investors. For these

\footnotetext{
${ }^{11}$ A body of literature on behavioral finance is persuasive of the relation between investor sentiment and stock market liquidity. In this regard, Tetlock (2007) finds that (i) unusually high or low levels of investor pessimism predict high market trading volume and (ii) high levels of media pessimism predict downward pressure on market prices.

12 If one excludes the Dot.Com period (i.e.,1997-2000) the Financials sector becomes the most liquid sector in our sample.

13 This could be due to the fact that hosting the World Cup stimulates aggregate investment that has a positive effect on the aggregate stock market, thus neutralizing (partially) the negative sport sentiment effect. Detailed results available in the Supplementary Appendix.

${ }^{14}$ See Kaplanski and Levy (2010a) for a detailed discussion of these arguments. Detailed results available in the Supplementary Appendix.
} 
Table 3

Summary table.

\begin{tabular}{lccccc}
\hline Portfolio & $\begin{array}{c}\text { End-of-period } \\
\text { out-PRFM value } \\
\text { of } 100 \text { USD }\end{array}$ & $\begin{array}{c}\text { Ann. out-PRFM } \\
\text { over } \\
\text { Benchmark (\%) }\end{array}$ & $\begin{array}{c}\text { Sharpe } \\
\text { Ratio }\end{array}$ & $\begin{array}{c}\text { Ann. Turnover } \\
\text { by } \\
\text { Volume Growth (\%) }\end{array}$ & $\begin{array}{c}\text { Avg Turnover } \\
\text { by Volume } \\
\text { over Market Value }\end{array}$ \\
\hline Basic Materials & 266.1 & 0.336 & 2.79 & 2.1 & 0.13 \\
Consumer Goods & 487.1 & 0.422 & 3.42 & 3.4 & 0.12 \\
Consumer Services & 594.3 & 0.422 & 3.5 & 4.1 & 0.14 \\
Financials & 1201.7 & 0.796 & 3.36 & 5.5 & 0.14 \\
Health Care & -152.1 & -0.045 & 4.62 & 2.7 & 0.08 \\
Industrials & 451.8 & 0.241 & 3.68 & 3.3 & 0.09 \\
Oil \& Gas & 487.9 & 0.34 & 3.18 & 4.3 & 0.22 \\
Technology & 138.3 & 0.209 & 2.49 & 6.6 & 0.14 \\
Telecommunications & 626 & 0.613 & 3.24 & 4.2 & 0.11 \\
Utilities & 172.3 & 0.091 & 4.49 & 1.5 & \\
NYSE Composite & 181.4 & 0.361 & 2.9 & & \\
S\&P500 & 173.8 & 0.355 & 2.81 & &
\end{tabular}

Notes: This table summarizes the performance of sell-and-hold trading strategies for the Basic Materials, Consumer Goods, Consumer Services, Financials, Health Care, Industrials, Oil \& Gas, Technology, Telecommunications, Utilities, NYSE Composite and S\&P500 stock indices. Annualized percentage end-of-period outperformance and Sharpe ratio are used to evaluate the performance of trading strategies. The end-of-period outperformance value of a given trading strategy is the difference between the sell-and-hold strategy for each portfolio and and its respective long-only benchmark investment of 100 USD. The Sharpe-Ratio is defined as the mean return of the sell-and-hold strategy over its standard deviation. A $0.5 \%$ transaction cost for getting in or out of the market is included. The last two columns report two liquidity measures. Annualized turnover by volume growth reports the annualized growth rate of turnover by volume for each long-only benchmark portfolio. The last column presents turnover by volume divided by market capitalization averaged over the sample period.

reasons, sport sentiment may affect different investors (i.e., local investors) and, thus, different sectors such as Oil \& Gas. ${ }^{15}$ A possible future research topic would be to understand the salient characteristic that makes those sectors compatible with the sport sentiment of local investors in Europe.

\section{Exploiting Cross-Sector World Cup Effects}

Based on the empirical evidence reported in the previous section we seek to build a profitable trading strategy. We assume that an investor who invests in a particular sector is willing to reallocate her wealth to the 3 month T-Bill during a World Cup period (i.e., underweight the sector). Differently, when no World Cup is taking place, the investor keeps her wealth invested in the sector portfolio. Figure 2 (panel A) depicts the cumulative outperformance of this trading strategy over its respective benchmark portfolio (i.e., a long-only position in a particular sector over a period from 01.01.1974 to 31.12.2014). Following Kaplanski and Levy (2010a), we assume transaction costs of 0.5\%. For illustration purposes we report only Financials, the average across the remaining nine sectors, the NYSE Composite and the S\&P 500. However, on a sectorby-sector comparison Financials still exhibit the highest cumulative outperformance. Panel B depicts the cumulative return of each sector averaged across all World Cup games taken place between 1974 and $2014 .{ }^{16}$ Finally, in Panel C we report the average Cumulative Abnormal Returns (CARs) around the first match day for the Financials sector and the average across all remaining sectors.

These three performance indicators clearly depict that underweighting the Financials sector during the World Cup games leads to superior returns as opposed to a simple long-only strategy in the same sector. ${ }^{17}$ When considering the whole US market, as proxied by NYSE Composite and S\&P 500, the underweighting strategy yields a positive overall cumulative return, but smaller than the return obtained by using the strategy based on the Financials sector only.

\section{Concluding Remarks}

Does investor sentiment spread evenly across different industrial sectors? In this paper we use international soccer results to study the effect of investors' sentiment on US industrial sectors. We find that sport sentiment affects mainly the Financials sector but not other sectors. Based on this result, we develop a simple and profitable trading strategy to exploit the sectoral sentiment effect. We argue that the sectoral effect of investor sentiment depends on the kind of sentiment under analysis. In this paper, we consider sport sentiment that, as argued in the previous literature, is more likely to affect foreign investors than local investors in the US. As a result, the relationship between sport sentiment and the Financials sector

\footnotetext{
15 This is also in line with the result of Edmans et al. (2007).

${ }^{16}$ Since the length of the eleven World Cup periods varies from 20 to 26 days, we depict the average strategy performance for the first 20 days.

17 Note that even after the Financial crisis in 2008 the underweighting strategy is most profitable among all sectors and yields an annualized outperformance of $0.796 \%$.
} 
Panel A: Cumulative Outperformance

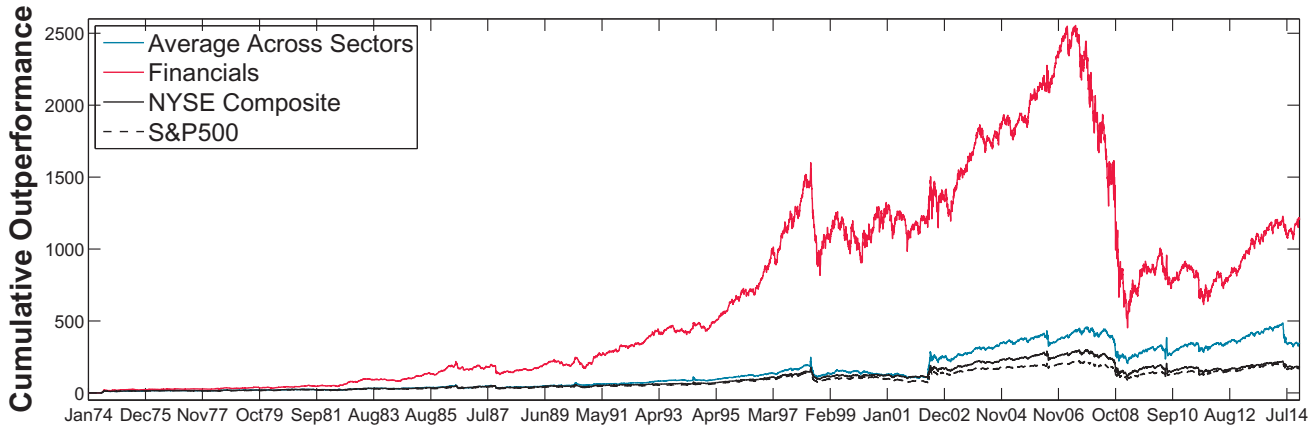

Panel B: Sell and Hold Strategy

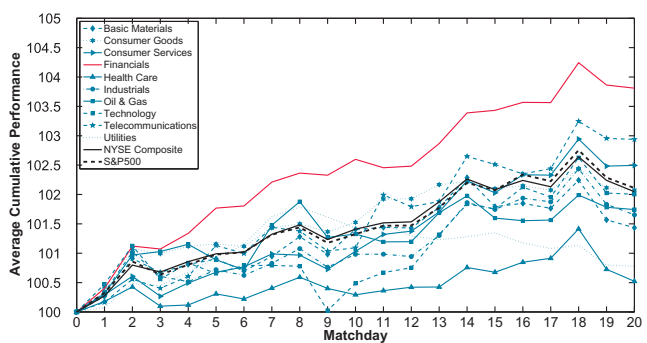

PANEL C: CARS

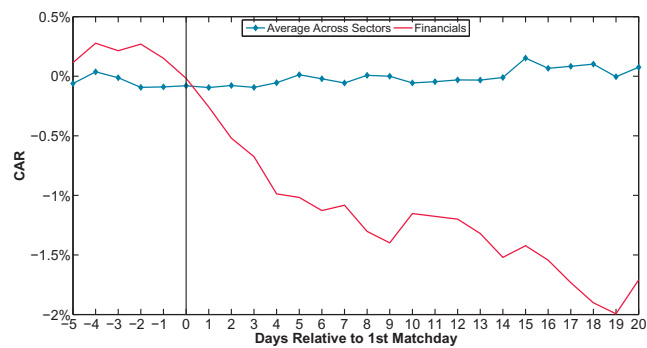

Fig. 2. Exploiting the World Cup Effect. Notes: Panel A depicts the cumulative outperformance of the Financials sector in excess of its benchmark portfolio. The Financials trading portfolio invests $100 \%$ in the Financials sector during non-World Cup days but reduces its exposure during World Cup periods. During the World Cup, it has a 0\% exposure to the Financials sector and 100\% exposure to the $3 \mathrm{~m}$ T-Bills. The benchmark portfolio for Financials, is the sector itself, i.e. $100 \%$ Financials over the whole period from 01.01.1974 - 31.12.2014. The outperformance is the difference between the Financials trading portfolio and the Financials benchmark portfolio. The same strategy is applied to all other sectors, the NYSE Composite Index and the S\&P500. The cumulative outperformance is averaged across sectors excluding Financials. Transaction costs of $0.5 \%$ for getting in or out of the market are included. Panel B depicts the average cumulative performance of the ten sectors and the benchmark indices S\&P 500 and NYSE Composite. The investment strategy is a simple short position taken in a sector or benchmark portfolio at the beginning of a World Cup period and held until its end. The length of the eleven World Cup periods under consideration varies from 20 to 26 days. This figure depicts the average strategy performance during the first 20 days. Panel $C$ depicts the average cumulative residuals around the first matchday $(t=0)$ for the Financials sector (red line) and the average across the remaining nine sectors (blue-diamond line). The residual on day $t$ is calculated as the difference between observed rate of return and the ex-post expected rate of return on day $t$. The one-factor capital asset pricing model $r_{t}=\alpha+\beta r_{m, t}+\epsilon_{t}$, where $r_{t}$ is the sector return and $r_{m, t}$ is the S\&P 500 return, is estimated using a 252-day estimation window.

might be due to the relatively high liquidity that makes the Financials sector more attractive to foreign investors. However, we believe that different kinds of investor sentiment (for instance, those based on meteorological conditions, seasonal diseases, temperature or lunar phases) might affect the behavior of other types of investors (for instance, local investors in the US) and, thus, might have a more pronounced effect on sectors (or stocks) other than Financials. This topic is left for future research.

\section{Acknowledgment}

We thank Brian Lucey (the Editor) and two anonymous referees for their valuable feedback. We also would like to thank A. Ciarlone, A. Gioffré, R. Pancrazi and F. Silvestri along with seminar participants at the 2015 Paris Financial Management Conference for helpful suggestions and discussions. Some of the work on this paper was completed while Donadelli and Riedel were visiting Portsmouth Business School. All remaining errors are our own.

\section{Supplementary material}

Supplementary material associated with this article can be found, in the online version, at 10.1016/j.frl.2016.03.023

\section{References}

Baca, S.P., Garbe, B.L., Weiss, R.A., 2000. The rise of sector effects in major equity markets. Financial Analysts Journal 56 (5), $34-40$.

Baker, M., Wurgler, J., 2006. Investor sentiment and the cross-section of stock returns. The Journal of Finance LXI, 1645-1680.

Bollena, J., Maoa, H., Zengb, X., 2011. Twitter mood predicts the stock market. Journal of Computational Science 2, 1-8.

Brooks, R., Negro, M.D., 2004. The rise in comovement across national stock markets: market integration or it bubble? Journal of Empirical Finance 11, $659-680$.

Brown, G.W., Cliff, M.T., 2004. Investor sentiment and the near-term stock market. Journal of Empirical Finance 11, 1-27. 
Brown, G.W., Cliff, M.T., 2005. Investor sentiment and asset valuation. The Journal of Business 78, 405-440.

Cao, M., Wei, J., 2005. Stock market returns: A note on tempereture anomaly. Journal of Banking and Finance 29, 1559-1573.

Chen, M.P., Chen, P.F., Lee, C.C., 2013. Asymmetric effects of investor sentiment on industry stock returns: Panel data evidence. Emerging Markets Review 14, 35-54.

Da, Z., Engelberg, J., Gao, P., 2015. The sum of all fears investor sentiment and asset prices. The Review of Financial Studies 28, 1-32.

Dahlquist, M., Robertsson, G., 2001. Direct foreign ownership, institutional investors, and firm characteristics. Journal of Financial Economics 59, 413-440.

Donadelli, M., Paradiso, A., 2014. Is there heterogeneity in financial integration dynamics? evidence from country and industry emerging market equity indexes. Journal of International Financial Markets, Institutions and Money 32, 184-218.

Donadelli, M., Persha, L., 2014. Understanding emerging market equity risk premia: Industries, governance and macroeconomic policy uncertainty. Research in International Business and Finance 30, 284-309.

Edmans, A., García, D., Norli, Ø., 2007. Sports sentiment and stock returns. Journal of Finance 62, $1967-1998$.

Griffin, J.M., Stulz, R.M., 2001. International competition and exchange rate shocks: a cross-country industry analysis of stock returns. Review of Financial Studies 14 (1), 215-241.

Hirshleifer, D., Shumway, T., 2003. Good day sunshine: Stock returns and the weather. Journal of Finance 58, $1009-1032$.

Huang, C., Yang, X., Yang, X., 2014. An empirical study of the effect of investor sentiment on returns of different industries. Mathematical Problems in Engineering 2014, 1-11.

Kamstra, M.J., Kramer, L.A., Levi, M.D., 2003. Winter blues: A sad stock market cycle. American Economic Review 93 (1), $324-343$.

Kaplanski, G., Levy, H., 2010a. Exploitable predictable irrationality: The FIFA world cup effect on the U.S. stock market. Journal of Financial and Quantitative Analysis 45, 535-553. doi:10.1017/S0022109010000153.

Kaplanski, G., Levy, H., 2010b. Sentiment and stock prices: The case of aviation disasters. Journal of Financial Economics 95, 174-201.

Kaplanski, G., Levy, H., 2012. The holiday and yom kippur war sentiment effects: The tel aviv stock exchange (TASE). Quantitative Finance 12, 1283-1298.

Kaplanski, G., Levy, H., 2014. Sentiment, irrationality and market efficiency: The case of the 2010 FIFA world cup. Journal of Behavioral and Experimental Economics 49, 35-43.

Lux, T., 2011. Sentiment dynamics and stock returns: the case of the German stock market. Empirical Economics 41, 663-679.

Nandha, M., Faff, R., 2008. Does oil move equity prices? a global view. Energy Economics 30, 986-997.

Palomino, F., Renneboog, L., Zhang, C., 2009. Information salience, investor sentiment, and stock returns: The case of British soccer betting. Journal of Corporate Finance 15, 368-387.

Saunders, E., 1993. Stock prices and wall street weather. The Journal of Finance 83, 1337-1345.

Tetlock, P.C., 2007. Giving content to investor sentiment: The role of media in the stock market. The Journal of Finance 62, 1139-1168.

Uygur, U., Tas, O., 2014. The impact of investor sentiment on different economic sector. Borsa Instanbul Review 14-4, $236-241$.

Yuan, K., Zheng, L., Zhu, Q., 2006. Are investors moonstruck? lunar phases and stock returns. Journal of Empirical Finance $13,1-23$. 